\title{
Backwasting rate on debris-covered Koxkar glacier, Tuomuer mountain, China
}

\author{
HAN Haidong, WANG Jian, WEI Junfeng, LIU Shiyin \\ State Key Laboratory of Cryospheric Sciences, Cold and Arid Regions Environmental and Engineering Research Institute, \\ Chinese Academy of Sciences, 320 Donggang West Road, Lanzhou 730000, China \\ E-mail: hhd@Izb.ac.cn
}

\begin{abstract}
A physically based energy-balance model with improved parameterization of solar radiation for a sloped ice surface has been developed to estimate the backwasting rate of an ice cliff in a debris-covered area. The model has been tested against observations between 5 August and 5 September 2008 on 38 ice cliffs in the debris-covered area of Koxkar glacier, Tuomuer mountain, China. We calculated that the energy-balance model gave a good estimate of the backwasting rates, with errors in the range $\pm 1.96 \mathrm{~cm} \mathrm{~d}^{-1}$ and root-mean-square errors of $0.99 \mathrm{~cm} \mathrm{~d}^{-1}$. Errors arising from setting of surface albedo and turbulent flux parameterization were limited. We found that shortwave radiation is the most important heat source for ice-cliff ablation, contributing about $76 \%$ of the total heat available for ice melt, while the sensible heat flux provides nearly $24 \%$ of the total heat for ice-cliff wastage. The latent heat flux and net longwave radiation are comparatively small according to the model calculation. The mean backwasting rate of ice cliffs in the debris-covered area of Koxkar glacier is estimated at $7.64 \mathrm{~m} \mathrm{a}^{-1}$ when the winter ablation is neglected. With this annual backwasting rate and given a mean slope angle of $46.4^{\circ}$, the backwasting of ice cliffs produces about $1.60 \times 10^{6} \mathrm{~m}^{3}$ of meltwater, accounting for about $7.3 \%$ of the total melt runoff from the debris-covered area.
\end{abstract}

\section{INTRODUCTION}

The Tuomuer mountain district is the largest glacierized area in the Tien Shan, China, with a total of 629 glaciers covering an area of $3850 \mathrm{~km}^{2}$ (Su and Gao, 1985; Han, 2007). A striking glaciological feature of this region is the development of many huge dendritic valley glaciers (called Tuomuer-type valley glaciers by Chinese glaciologists for their unique characteristics). Another impressive characteristic of these glaciers is a heavy supraglacial debris cover in the ablation zone. The data compiled in the Tien Shan volume of the Chinese Glacier Inventory (Xie and others, 1987) show that $>60 \%$ of the ablation area of Tuomuer-type valley glaciers is covered by supraglacial debris. Since, due to thermal isolation, a debris layer with thickness greater than $\sim 20 \mathrm{~cm}$ may inhibit melting of ice underneath (Østrem, 1959; Loomis, 1970; Fujii, 1977; Mattson and others, 1993), the extensive debris entrainments on Tuomuer-type valley glaciers (thickness typically $20-100 \mathrm{~cm}$ ) greatly suppress melting and prevent rapid glacier wastage. Wang and others (1987) reported that, at locations around $4000 \mathrm{~m}$ a.s.I. on West Qiongtailan Glacier, ice ablation was $20-30 \%$ less under a $10 \mathrm{~cm}$ thick debris cover, and about $50 \%$ less under a $20 \mathrm{~cm}$ thick debris cover, than under a clean ice layer. This implies that, compared with glaciers covered by clean ice and snow, glaciers with extensive supraglacial debris cover may be more stable against the warming climate, in terms both of dimensions (length and area) and of meltwater production.

The hydrology of this debris-covered area is, however, complicated by the existence of many ice cliffs and exposed supraglacial ponds or lakes. Backwasting of ice cliffs can be significant during the ablation period due to more intense melting over the bare-ice slopes than under the debris mantle. Melting of ice cliffs may therefore be an important meltwater source in the debris-covered area. Sakai and others (1998) reported that ice cliffs, with only $1.8 \%$ of the areal coverage, contributed about $69 \%$ of the total ablation within the debris-covered area on Lirung glacier, Himalaya. A similarly significant mass loss due to rapid backwasting can be found in numerous debris-covered glaciers worldwide (e.g. Tasman Glacier, New Zealand (Purdie and Fitzharris, 1999); Donjek Glacier, Yukon, Canada (Johnson, 1992); and Holmströmbreen, Svalbard (Schomacker and Kjær, 2008)). In the Tuomuer mountain district, however, quantitative knowledge of ice-cliff backwasting over debriscovered glaciers is limited.

This paper describes quantitative assessments of ice-cliff backwasting in the debris-covered area on Koxkar glacier on the basis of energy-balance modeling. Field measurements of the backwasting rate of ice cliffs were carried out for model calibration and validation on 38 ice cliffs in the debris-covered area of Koxkar glacier between 5 August and 5 September 2008. Our main aims here are to assess the predictability of backwasting rate using the energy-balance model and to quantify the annual backwasting rate on the basis of model calculation.

\section{STUDY AREA}

Koxkar glacier $\left(41^{\circ} 42^{\prime}-41^{\circ} 53^{\prime} \mathrm{N}, 79^{\circ} 59^{\prime}-80^{\circ} 10^{\prime} \mathrm{E}\right.$; Fig. 1) is a typical Tuomuer-type glacier (Su and Gao, 1985) originating from Koxkar mountain (6342 m a.s.l.), and flows southeast to the terminus at $3060 \mathrm{~m}$ a.s.l. The glacier is $25.1 \mathrm{~km}$ long and covers an area of $83.56 \mathrm{~km}^{2}$. The equilibrium line occurs at $4300 \mathrm{~m}$ a.s.l. in the icefall, from the foot of which a $15.5 \mathrm{~km}$ long, debris-mantled glacier tongue appears. The supraglacial debris covers $\sim 15.6 \mathrm{~km}^{2}$, accounting for $83 \%$ of the total ablation area. Debris thickness ranges from $<0.01 \mathrm{~m}$ on the upper reach of the ablation area and on ice-cliff slopes to $>3.0 \mathrm{~m}$ near the glacier snout (Han and others, 2006).

Figure 2 is a map of the ice cliffs and supraglacial ponds/ lakes, based on a panchromatic Système Probatoire pour 


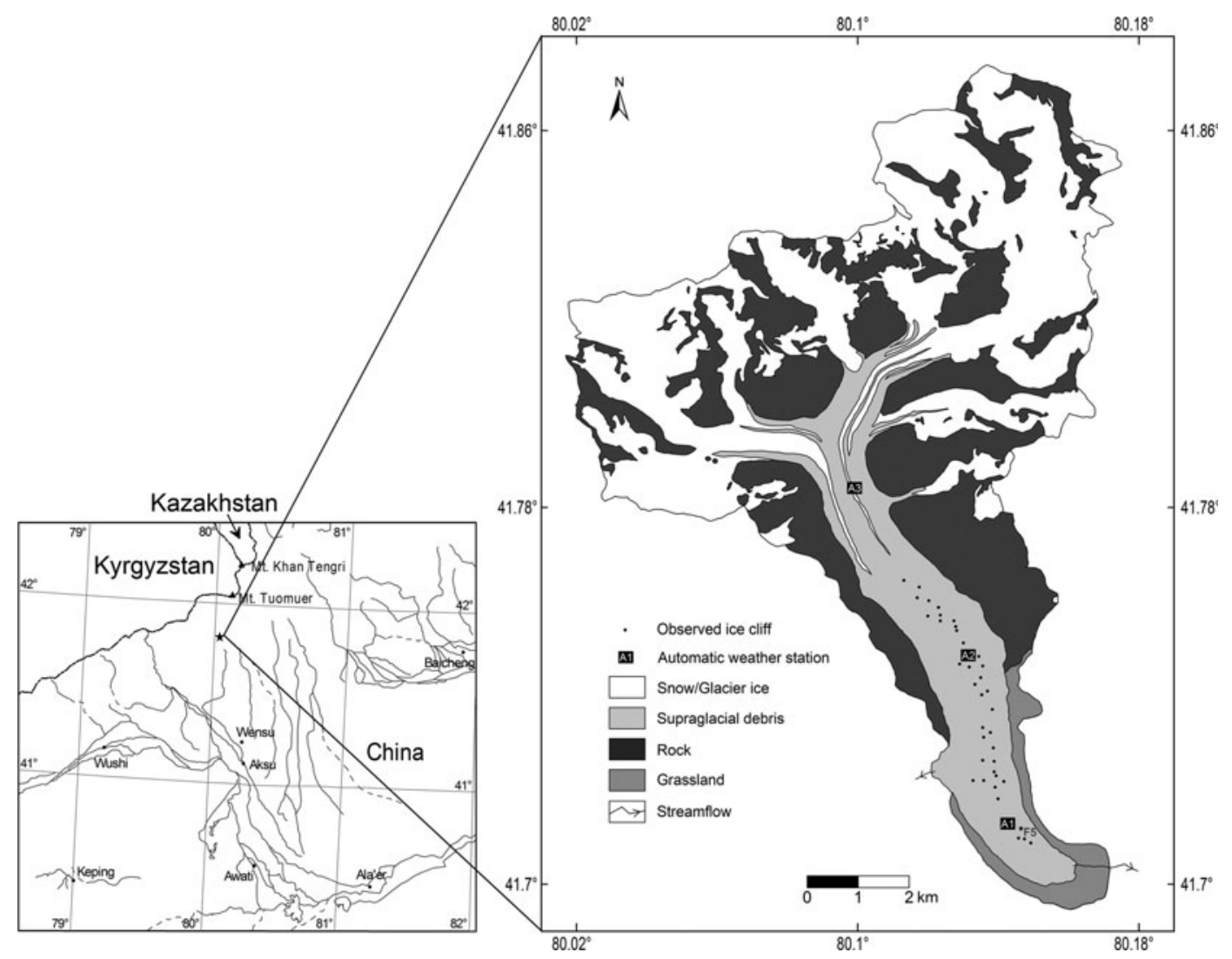

Fig. 1. Location of Koxkar glacier, Tuomuer mountain, China.

I'Observation de la Terre (SPOT) image (5 $\mathrm{m}$ resolution) taken in late April 2006. The ice cliffs are mainly exposed on the debris-covered area $1.5-10 \mathrm{~km}$ up-glacier from the terminus (3060 ma.s.l.) and tend to be developed in the medial part of the glacier. This may be due to higher ice speed in the centre of the glacier than at the margins (Benn and Evans, 1998). Calculation based on Figure 2 shows that the projected area of the ice cliffs over the horizontal plane was $\sim 221330 \mathrm{~m}^{2}$ by the end of April 2006, accounting for about $1.13 \%$ of the total debris-covered area.

The mean annual air temperature observed near the terminus of the glacier is $0.77^{\circ} \mathrm{C}$, while the mean summer temperature is as high as $7.74^{\circ} \mathrm{C}$ (Han and others, 2008). The melt season over Koxkar glacier starts in May and continues for 6 months until the end of October. Mean annual precipitation near the terminus is $\sim 608 \mathrm{~mm}$, of which $>80 \%$ occurs during the ablation period (Han and others, 2008). The melt runoff measured near the snout is $\sim 102.86$ $\times 10^{6} \mathrm{~m}^{3} \mathrm{a}^{-1}$, of which $93.6 \%$ occurs during the melt season (Han and others, in press).

\section{FIELD OBSERVATIONS}

Backwasting, defined as the lateral retreat of steep ice-walls or ice-cored slopes (Pickard, 1984; Krüger, 1994; Krüger and Kjær, 2000), is the term commonly used to quantify the wastage of a sloped ice mass with debris mantle. On Koxkar glacier, ice cliffs for backwasting measurements were selected so that the main ice-cliff characteristics (e.g. altitudinal distribution, scale, orientation and inclination angle) were represented. The elevations of observed ice cliffs ranged from 3180 to $3578 \mathrm{~m}$. Generally a fixed outstanding boulder behind the top edge of the ice cliff was painted as a benchmark so that a tape could be used to measure the distance from the ice cliff to this benchmark (Fig. 3). Alternatively, when such a fixed benchmark was not available, a graduated ablation stake was inserted perpendicularly into the bare-ice slope so that the melt rate of the ice cliff could be measured. The backwasting rate was then calculated from the perpendicular melt and slope angle of the cliff. The slope angles for all selected ice cliffs were measured using a geological compass. Since the bare-ice slope of an ice cliff is often presented as a curved surface, slope angle measurements were conducted over different parts of the ice cliffs to derive mean values. It was observed that slope angles of measured ice cliffs were $30-64^{\circ}$, with a mean of $46.4^{\circ}$. Azimuth angles of all 38 ice cliffs were measured near the center of the top edge using a geological compass. The observed ice cliffs were found to face in a variety of directions, the number near north being larger than near south. This concurs with a previous study (Han and others, 2006). In addition, the face area, mean height and mean width of each ice cliff were recorded using a tape measure. Backwasting measurements of all selected ice cliffs began between 5 and 11 August. Repeat measurements were carried out between 31 August and 5 September, allowing mean backwasting rates for each ice cliff to be measured over at least 25 days. To facilitate model calculation, the vertical ice melt (Fig. 3) is also employed because the analysis of energy-balance elements is generally computed over a unit horizontal area. The observed vertical melt rate can be inferred from the observed backwasting rate through a trigonometric transformation.

The meteorological variables were captured by three automatic weather stations (AWSs) at 3212 ma.s.l. (site $A_{1}$ ), 


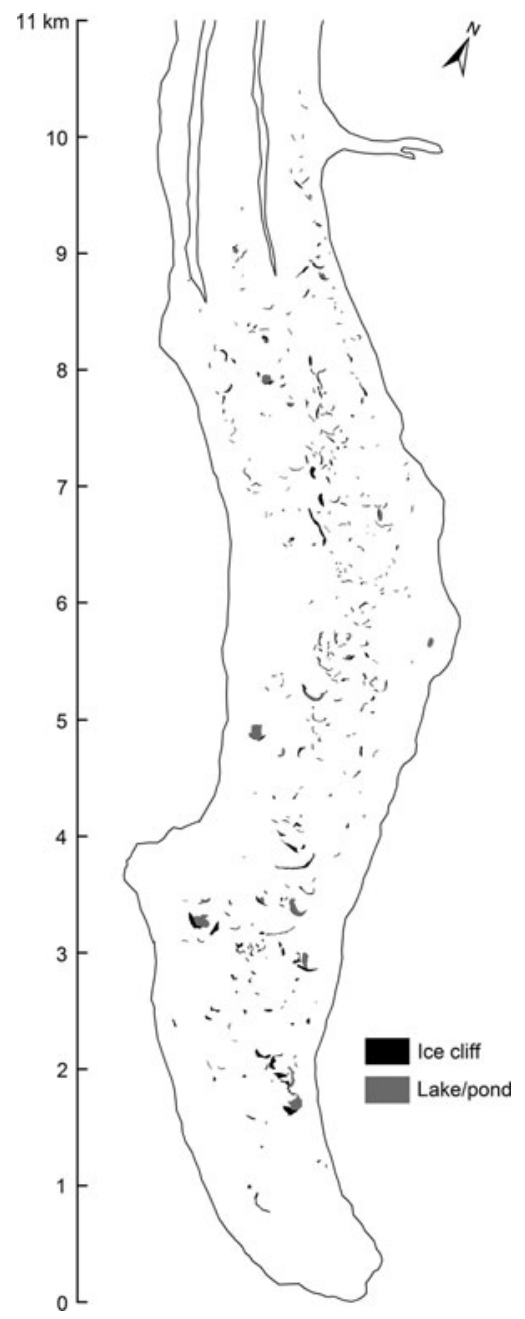

Fig. 2. Distribution of ice cliffs and supraglacial ponds/lakes in the debris-covered area on Koxkar glacier, mapped from a panchromatic SPOT image of 27 April 2006.

3433 ma.s.l. (site $A_{2}$ ) and 3730 ma.s.l. (site $A_{3}$ ) (Fig. 1). Sites $A_{1}$ and $A_{2}$ are covered by continuous supraglacial debris, and the AWS at site $A_{3}$ was installed on narrow clean ice with debris cover distributed on the western and eastern sides. The meteorological sensors on each AWS are listed in

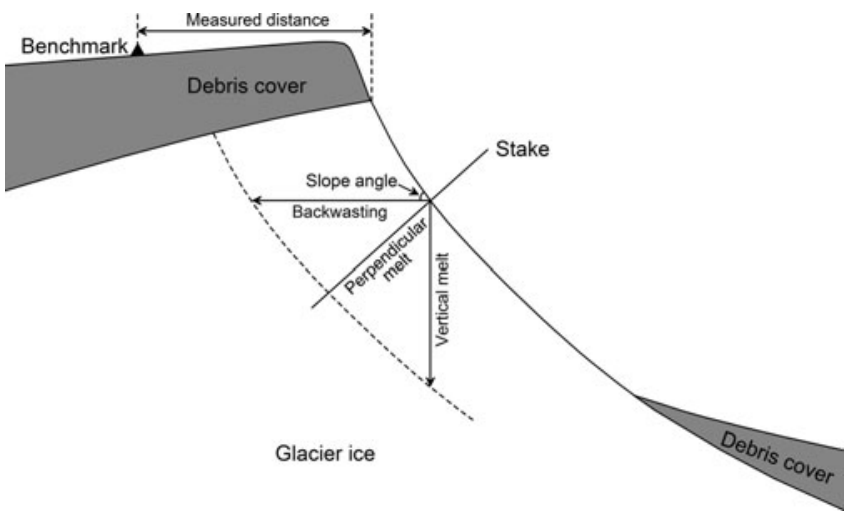

Fig. 3. Schematic diagram of the measurements of ice-cliff backwasting.

Table 1, and mean weather conditions during the observation period are given in Table 2.

\section{ENERGY-BALANCE MODEL}

The energy-balance equation for a unit horizontal area over an ice-cliff slope can be written as

$$
Q_{\mathrm{m}}=I_{\mathrm{n}}+L_{\mathrm{n}}+H+\mathrm{LE},
$$

where $Q_{\mathrm{m}}$ is heat for vertical ice melt $\left(\mathrm{W} \mathrm{m}^{-2}\right), I_{\mathrm{n}}$ and $L_{\mathrm{n}}$ are net short- and longwave radiation fluxes $\left(\mathrm{W} \mathrm{m}^{-2}\right)$, and $H$ and LE are turbulent sensible and latent heat fluxes $\left(\mathrm{W} \mathrm{m}^{-2}\right)$. Heat conduction into the glacier ice and the specific heat of rainfall are neglected since they are small compared with the above terms. All fluxes are taken positive when they are toward the ice-cliff face.

The net shortwave radiation flux on an ice-cliff slope in a unit horizontal area is given by

$$
I_{\mathrm{n}}=\left(I_{\mathrm{s}}+D_{\mathrm{s}}+D_{\mathrm{t}}\right)(1-\alpha) / \cos \beta,
$$

where $I_{\mathrm{s}}$ is the direct solar irradiance from the sky $\left(\mathrm{W} \mathrm{m}^{-2}\right)$, $D_{\mathrm{s}}$ is the diffuse sky irradiance $\left(\mathrm{W} \mathrm{m}^{-2}\right), D_{\mathrm{t}}$ is the diffuse irradiance from the surrounding terrain $\left(\mathrm{W} \mathrm{m}^{-2}\right), \alpha$ is the surface albedo of the ice-cliff slope, taken to be 0.37 according to our observation at site $A_{3}$, and $\beta$ is the angle of ice-cliff slope. Considering the shading effect of surrounding topography, the direct shortwave radiation reaching a slope

Table 1. AWS meteorological sensors

\section{AWS}

$\mathrm{A}_{1}$

$\mathrm{A}_{2}$

\begin{tabular}{|c|c|c|c|}
\hline Wind sensor & $\begin{array}{l}05103 \text { Wind Monitor } \\
\text { (Campbell Scientific, Inc.) }\end{array}$ & $\begin{array}{l}05103 \text { Wind Monitor } \\
\text { (Campbell Scientific, Inc.) }\end{array}$ & $\begin{array}{l}05103 \text { Wind Monitor } \\
\text { (Campbell Scientific, Inc.) }\end{array}$ \\
\hline Mounting height & $2 \mathrm{~m}$ & $2 \mathrm{~m}$ & $2 \mathrm{~m}$ \\
\hline $\begin{array}{l}\text { Air temperature and relative } \\
\text { humidity probe }\end{array}$ & $\begin{array}{l}\text { MP101A (Rotronic Instrument } \\
\text { Corp.) }\end{array}$ & $\begin{array}{l}\text { HMP45C (Campbell Scientific, } \\
\text { Inc.) }\end{array}$ & $\begin{array}{l}\text { MP101A (Rotronic Instrument } \\
\text { Corp.) }\end{array}$ \\
\hline Mounting height & $2 \mathrm{~m}$ & $2 \mathrm{~m}$ & $2 \mathrm{~m}$ \\
\hline $\begin{array}{l}\text { Incoming and outgoing solar } \\
\text { radiation sensor }\end{array}$ & $\begin{array}{l}\text { TBQ-8 Pyranometer (Jinzhou } \\
\text { Sunshine Sci \& Tech) }\end{array}$ & & $\begin{array}{c}\text { CM3 Pyranometer (Campbell } \\
\text { Scientific, Inc.) }\end{array}$ \\
\hline Mounting height & $1.5 \mathrm{~m}$ & & $1.5 \mathrm{~m}$ \\
\hline $\begin{array}{l}\text { Precipitation gauge } \\
\text { Mounting height }\end{array}$ & & $\begin{array}{c}\text { T-200B (GEONOR Inc.) } \\
1.5 \mathrm{~m}\end{array}$ & \\
\hline Data logger & CR1000 (Campbell Scientific, Inc.) & CR200 (Campbell Scientific, Inc.) & CR23X (Campbell Scientific, Inc.) \\
\hline Record interval & 1 hour & 1 hour & 1 hour \\
\hline
\end{tabular}

$\mathrm{A}_{3}$ 
Table 2. Statistics of meteorological variables measured by AWS on Koxkar glacier from 5 August to 5 September 2008

\begin{tabular}{|c|c|c|c|c|}
\hline & & \multicolumn{3}{|c|}{ AWS } \\
\hline & Statistic & $A_{1}$ & $\mathrm{~A}_{2}$ & $\mathrm{~A}_{3}$ \\
\hline \multirow[t]{2}{*}{ Wind speed $\left(\mathrm{m} \mathrm{s}^{-1}\right)$} & Mean & 2.64 & 3.05 & 2.51 \\
\hline & Maximum & 10.96 & 9.50 & 7.07 \\
\hline Wind direction & Predominant & Northwest & Northwest & Northwest \\
\hline \multirow[t]{3}{*}{ Air temperature $\left({ }^{\circ} \mathrm{C}\right)$} & Mean & 9.86 & 6.81 & 4.76 \\
\hline & Maximum & 16.60 & 13.69 & 12.02 \\
\hline & Minimum & 1.31 & -0.71 & -3.21 \\
\hline Relative humidity (\%) & Mean & 49.09 & 58.61 & 64.01 \\
\hline Incoming solar radiation $\left(\mathrm{MJ} \mathrm{m}^{-2} \mathrm{~d}^{-1}\right)$ & Mean & 24.29 & & 16.65 \\
\hline Precipitation (mm) & Total & & 369.45 & \\
\hline
\end{tabular}

can be computed by (Garnier and Ohmura, 1968)

$$
\begin{aligned}
I_{\mathrm{s}}=I_{\mathrm{b}}\{[ & {[\sin \phi \cos \omega)(-\cos A \sin \beta) } \\
& -\sin \omega(\sin A \sin \beta)+(\cos \phi \cos \omega) \cos \beta] \\
& \cdot \cos \delta+[\cos \phi(\cos A \sin \beta)+\sin \phi \cos \beta] \sin \delta\} \\
& \theta \leq H_{\mathrm{s}} \\
I_{\mathrm{s}}=0 & \theta>H_{\mathrm{s}}
\end{aligned}
$$

where $I_{\mathrm{b}}$ is the direct normal irradiance which is the part of the extraterrestrial radiation penetrating the atmosphere $\left(\mathrm{W} \mathrm{m}{ }^{-2}\right), \phi$ is the latitude of the slope $\left({ }^{\circ}\right), \omega$ is hour angle, solar noon being zero and the morning being negative $\left(^{\circ}\right), A$ is the azimuth of the slope $\left(^{\circ}\right), \delta$ is the sun's declination, positive when the sun is north of the Equator $\left({ }^{\circ}\right), \theta$ is the solar zenith angle, and $H_{\mathrm{s}}$ is the horizon angle $\left(^{\circ}\right)$ in the direction of solar beam. The horizon angle, defined as the angle subtended by the lines extending from a point to the zenith and to the summit of the surrounding terrain in a given direction (Dozier and Frew, 1990), was computed from the Advanced Spaceborne Thermal Emission and Reflection Radiometer (ASTER) global digital elevation model (GDEM; $30 \mathrm{~m}$ resolution) in this study. The full solution of direct normal irradiance, $I_{\mathrm{b}}$, involves determination of a number of transmittances of solar radiation due to absorption and/or scattering by ozone, gas, water and aerosols (e.g. Iqbal, 1983; Chou and Suarez, 1999; Wong and Chow, 2001) and thus is derived indirectly in this study using global solar radiation observed at site $A_{1}$ or $A_{3}$ depending on the distance to the calculated ice cliff. It gives

$$
I_{\mathrm{b}}=\left(I_{\mathrm{o}}-D_{\mathrm{h}}\right) / \sin h,
$$

where $I_{\mathrm{o}}$ is observed global solar radiation $\left(\mathrm{W} \mathrm{m}^{-2}\right), D_{\mathrm{h}}$ is diffuse irradiance to a horizontal surface $\left(\mathrm{W} \mathrm{m}^{-2}\right)$ and $h$ is the solar elevation $\left({ }^{\circ}\right)$. Following Reindl and others (1990), $D_{\mathrm{h}}$ is obtained using the diffuse fraction $k_{\mathrm{d}}$ and clearness index $k_{t}$ (both dimensionless) by

$$
\begin{gathered}
D_{\mathrm{h}}=k_{\mathrm{d}} l_{\mathrm{O}} \\
k_{t}=I_{\mathrm{o}} / l_{\mathrm{E}} \\
k_{\mathrm{d}}=1.02-0.254 k_{t}+0.0123 \sin h \text { for } k_{t} \leq 0.3 \\
k_{\mathrm{d}}=1.4-1.749 k_{t}+0.177 \sin h \text { for } 0.3<k_{t} \leq 0.78 \\
k_{\mathrm{d}}=0.486 k_{t}-0.182 \sin h \text { for } k_{t} \geq 0.78,
\end{gathered}
$$

where the extraterrestrial radiation $I_{\mathrm{E}}\left(\mathrm{W} \mathrm{m}^{-2}\right)$ is given by

$$
I_{\mathrm{E}}=E_{\mathrm{O}} I_{\mathrm{SC}} \sin h,
$$

$I_{\mathrm{sC}}$ is the solar constant, taken as $1367 \mathrm{Wm}^{-2}$, and $E_{\mathrm{O}}$ (dimensionless) is the eccentricity correction-factor of the Earth's orbit. This is given by (Wong and Chow, 2001)

$$
\begin{aligned}
E_{\mathrm{o}}= & 1.00011+0.034221 \cos \Gamma+0.00128 \sin \Gamma \\
& -0.000719 \cos 2 \Gamma+0.000077 \sin 2 \Gamma,
\end{aligned}
$$

where $\Gamma$ is the day angle (rad) which is calculated as

$$
\begin{array}{r}
\Gamma=2 \pi\{N-79.6764-0.2422(\text { year }-1985) \\
+ \text { INT }[(\text { year }-1985) / 4]\} / 65.2422,
\end{array}
$$

where $N$ is the day number of the year. The diffuse sky irradiance incoming to the ice-cliff slope, $D_{\mathrm{s}}$ in Equation (2), can be obtained by introducing the isotropic sky-view factor, $V_{d}$ which accounts for the portion of the overlying hemisphere visible to a sloping surface (Dozier and Frew, 1990)

$$
\begin{gathered}
D_{\mathrm{s}}=V_{d} D_{\mathrm{h}} \\
V_{d}=\frac{1}{2 \pi} \int_{0}^{2 \pi}\left[\cos \beta \sin ^{2} H_{\phi}+\sin \beta \cos (\phi-A)\right. \\
\left.\cdot\left(H_{\varphi}-\sin H_{\varphi} \cos H_{\varphi}\right)\right] \mathrm{d} \phi,
\end{gathered}
$$

where $H_{\varphi}$ is the horizon angle (rad) for direction $\varphi$. The skyview factor for a given ice cliff was calculated such that the shading effects of local inclination of ice cliff and high-relief terrain at the glacier margin were better presented, while the effect of supraglacial topography around the ice cliff was loosely included due to the low resolution of the ASTER GDEM used in the calculation. Shortwave contribution from the surrounding terrain to the ice-cliff surface is

$$
D_{\mathrm{t}}=\alpha_{\mathrm{t}} l_{\mathrm{o}}\left(1-V_{\mathrm{d}}\right) \text {, }
$$

where $\alpha_{\mathrm{t}}$ is the average surface albedo of the surrounding terrain, taken to be 0.24 according to Han and others (2005).

Net longwave radiation can be split into incoming atmospheric longwave irradiance from the unobscured portion of $s k y, L_{s}$, longwave irradiance from surrounding terrain, $L_{\mathrm{t}}$, and outgoing longwave radiation, $L_{\mathrm{o}}$, which gives

$$
L_{\mathrm{n}}=\left(L_{\mathrm{s}}+L_{\mathrm{t}}-L_{\mathrm{o}}\right) / \cos \beta,
$$

where all irradiances are expressed in $\mathrm{Wm}^{-2} . L_{\mathrm{s}}$ is determined based on the work of Sridhar and Elliott (2002):

$$
L_{\mathrm{s}}=V_{d}\left[1.31\left(10 e_{\mathrm{a}} / T_{\mathrm{a}}\right)^{1 / 7} \sigma\left(T_{\mathrm{a}}+273.15\right)^{4}\right],
$$

where $\sigma$ is the Stefan-Boltzmann constant $(5.67 \times$ $10^{-8} \mathrm{~W} \mathrm{~m}^{-2} \mathrm{~K}^{-4}$ ), and $e_{\mathrm{a}}$ and $T_{\mathrm{a}}$ are the vapor pressure $(\mathrm{kPa})$ and air temperature $\left(^{\circ}\right)$ at screen height $(2 \mathrm{~m})$ respectively. Since air temperatures at the observed ice cliffs were not 
measured, temperatures for each ice cliff were obtained indirectly, using temperature lapse rates calculated from the air temperatures recorded at the three AWSs. This treatment is validated by the fact that during the study period the hourly air temperatures at the AWS are highly correlated (coefficient of determination $R^{2}=0.99$ between sites $\mathrm{A}_{1}$ and $\mathrm{A}_{2}$ and $R^{2}=0.96$ between sites $\mathrm{A}_{2}$ and $\mathrm{A}_{3}$ ). The mean lapse rates during the observation period were found to be $-1.29^{\circ} \mathrm{C}(100 \mathrm{~m})^{-1}$ between sites $A_{1}$ and $A_{2}$ and $-0.52^{\circ} \mathrm{C}(100 \mathrm{~m})^{-1}$ between sites $A_{2}$ and $A_{3}$. The air temperatures at observed ice cliffs can therefore be interpolated from temperature records measured at the nearest AWS. Since ground surface temperatures were also not available, the longwave irradiance from surrounding topography can be adequately computed assuming the ground radiates as a black-body radiator at screen air temperature (Cole, 1979), which gives

$$
L_{\mathrm{t}}=\sigma\left(T_{\mathrm{a}}+273.15\right)^{4}\left(1-V_{d}\right) .
$$

The outgoing longwave radiation from an ice-cliff surface is calculated by

$$
L_{\mathrm{o}}=\varepsilon \sigma\left(T_{\mathrm{s}}+273.15\right)^{4},
$$

where $\varepsilon$ is the effective emissivity of the glacier ice, assumed to be 0.97 in this study, and $T_{\mathrm{s}}$ is the surface temperature of the ice cliff $\left({ }^{\circ} \mathrm{C}\right)$, assumed constant at $0^{\circ} \mathrm{C}$.

The turbulent heat fluxes were calculated using formulations developed by Ambach (1986). The sensible heat flux was computed from temperature and wind speed:

$$
H=K_{\mathrm{s}} P\left(T_{\mathrm{a}}-T_{\mathrm{s}}\right) u,
$$

where $P$ is atmospheric pressure $(\mathrm{kPa})$, and $u$ is the wind speed derived from the nearby AWS $\left(\mathrm{m} \mathrm{s}^{-1}\right) . K_{\mathrm{s}}$ is the exchange coefficient that, for a neutral boundary layer with logarithmic profiles for wind speed and temperature, is given by

$$
K_{\mathrm{s}}=c_{p} k^{2} \rho_{0} /\left[P_{0} \ln \left(z / z_{0}\right) \ln \left(z / z_{0 T}\right)\right],
$$

where $c_{p}$ is the specific heat of air at constant pressure $\left(1004 \mathrm{~J} \mathrm{~kg}^{-1} \mathrm{~K}^{-1}\right), k$ is von Kármán's constant $(0.41), \rho_{0}$ is the standard density of air $\left(1.29 \mathrm{~kg} \mathrm{~m}^{-3}\right), P_{0}$ is the standard atmospheric pressure $(101.3 \mathrm{kPa}), z$ is the height above the ice surface at which the mean meteorological variables for the ice cliffs were retrieved from the adjacent AWS (2 $\mathrm{m}$ in the present case) and $z_{0}$ and $z_{0 T}$ are the roughness lengths for momentum and temperature profiles $(\mathrm{m})$, respectively. The latent heat flux is given by:

$$
\mathrm{LE}=K_{\mathrm{L}}\left(e_{\mathrm{a}}-e_{\mathrm{s}}\right) u,
$$

where $e_{\mathrm{s}}$ is the vapor pressure at the ice-cliff face, assumed to be the saturated vapor pressure at $0^{\circ} \mathrm{C}(0.611 \mathrm{kPa})$, and $K_{L}$ is the exchange coefficient for latent heat under the same assumptions as $K_{\mathrm{s}}$. $K_{L}$ is given by

$$
K_{L}=0.623 L k^{2} \rho_{0} /\left[P_{0} \ln \left(z / z_{0}\right) \ln \left(z / z_{0 \mathrm{e}}\right)\right],
$$

where $L$ is the latent heat of evaporation $\left(2.514 \times 10^{6} \mathrm{~J} \mathrm{~kg}^{-1}\right)$ and $z_{0 \mathrm{e}}$ is the roughness length for a logarithmic profile of vapor pressure $(\mathrm{m})$. The roughness length was calculated using Lettau's (1969) model modified for high-relief terrain, by

$$
z_{0}=0.5 h_{\mathrm{c}} \lambda_{\mathrm{f}}
$$

where $h_{\mathrm{c}}$ is the mean height of the ice cliff $(\mathrm{m})$, and $\lambda_{\mathrm{f}}$ is the frontal area density which is presented in this study as the degree of a slope exposed to the wind (dimensionless) and is

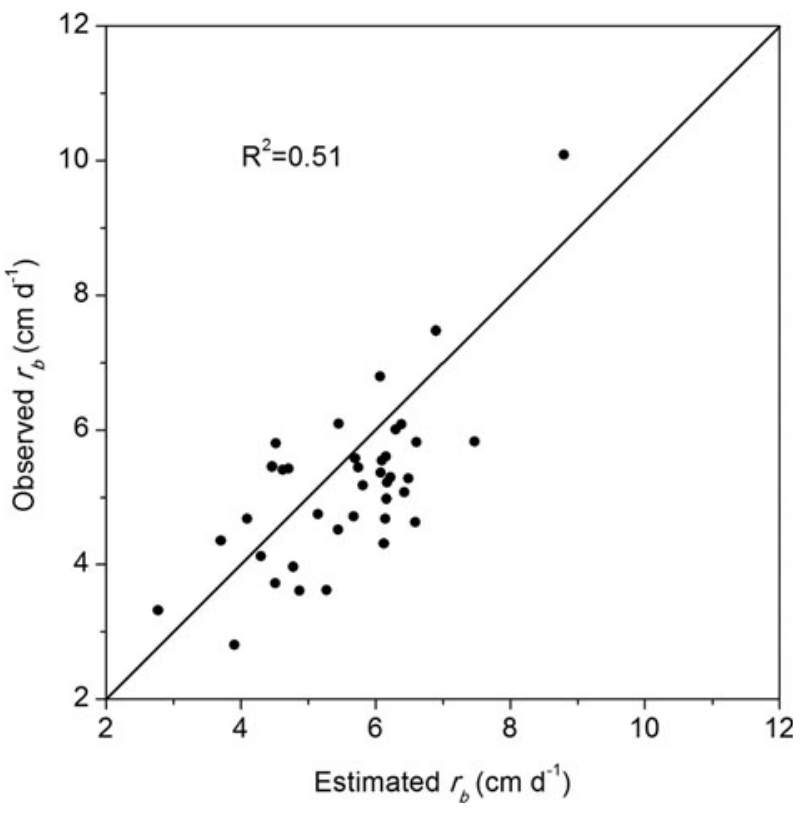

Fig. 4. Scatter diagram of estimated versus observed backwasting rates for all 38 ice cliffs during the observation period.

calculated by

$$
\lambda_{\mathrm{f}}=0.05 \sin \beta\left[1+\cos \left(A-W_{\mathrm{D}}\right)\right],
$$

where $W_{\mathrm{D}}$ is the wind direction $\left({ }^{\circ}\right) . z_{0 T}$ and $z_{0 \mathrm{e}}$ are assumed to be equal and are derived using Andreas' (1987) model,

$$
\ln \left(z_{0 T} / z_{0}\right)=0.317-0.565 \ln \left(R e_{*}\right)-0.183 \ln ^{2}\left(R e_{*}\right),
$$

where $R e_{*}$ is the roughness Reynolds number. This is given by

$$
\operatorname{Re}_{*}=u_{*} z_{0} / \nu
$$

where $\nu$ is the viscosity of air $\left(1.35 \times 10^{-5} \mathrm{~m}^{2} \mathrm{~s}^{-1}\right)$ and $u_{*}$ is the friction velocity $\left(\mathrm{m} \mathrm{s}^{-1}\right)$, estimated by

$$
u_{*}=u k / \ln \left(z / z_{0}\right) \text {. }
$$

The heat for vertical ice ablation, $Q_{m}$, is calculated from the energy-balance model. The daily ice-cliff backwasting, $r_{\mathrm{b}}$ $\left(\mathrm{cm} \mathrm{d}^{-1}\right)$, is obtained by

$$
r_{\mathrm{b}}=\sum_{t=0}^{23} 360000 Q_{\mathrm{m}} /\left(L_{f} \rho_{\mathrm{i}} \tan \beta\right),
$$

where $L_{f}$ is the latent heat of phase change of ice $(0.334 \mathrm{MJ}$ $\left.\mathrm{kg}^{-1}\right)$ and $\rho_{\mathrm{i}}$ is the density of ice $\left(900 \mathrm{~kg} \mathrm{~m}^{-3}\right)$.

\section{RESULTS AND DISCUSSIONS Model validation}

Figure 4 shows the relationship between estimated and observed backwasting rates, $r_{\mathrm{b}}$, for all 38 ice cliffs during the observation period. In general, the estimate is satisfied with errors of $\pm 1.96 \mathrm{~cm} \mathrm{~d}^{-1}$ for $r_{\mathrm{b}}$, with root-mean-square errors (RMSEs) of $0.99 \mathrm{~cm} \mathrm{~d}^{-1}$, but the results are by no means perfect. A number of factors can lower the performance of the proposed energy-balance model (e.g. errors in surface albedo, turbulent fluxes, roughness length and field observations).

The surface albedo, $\alpha$, is an important parameter that characterizes the reflectivity of the ground surface to the incident solar radiation. Since solar radiation generally contributes the majority of energy available for ice melt, 


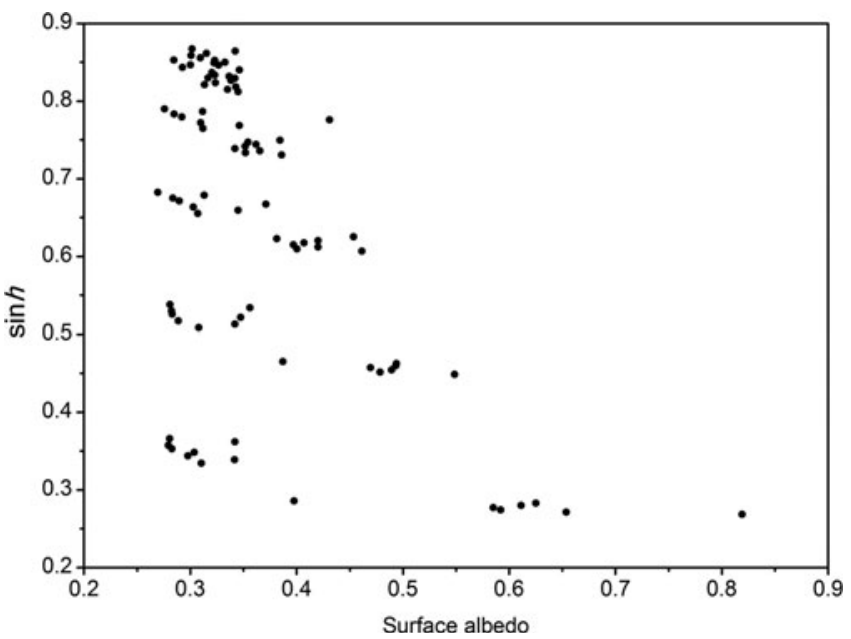

Fig. 5. Relationship between solar elevation, $h$, and albedo of ice surface observed at site $A_{3}$ from 5 August to 5 September 2008. Days with snow-covered surface were excluded.

determination of the surface albedo of glacier ice is of great importance in the model parameterization. In general, the albedo depends on the incident angle of the incoming radiation and surface properties. However, in areas with complex terrain and significant topographic shading, the numerical determination of ice surface albedo on the basis of incidence angle may be difficult. As demonstrated in Figure 5, no obvious relationship is found between the observed ice surface albedo and the solar elevation, and most observed albedo is distributed in the range $0.27-0.5$, with a mean of 0.37 . We supposed that the low correlation between ice surface albedo and solar elevation in the studied area may be due to the significant diffusivity of the surrounding terrain to the solar radiation. In our calculation the surface albedo was taken uniformly for all 38 ice cliffs. Note that the constant setup of the surface albedo in the model may overestimate the net shortwave radiation, and thus the backwasting rate, over the ice-cliff slope, especially for those slopes with northerly azimuth and large inclination angle, where the angle of

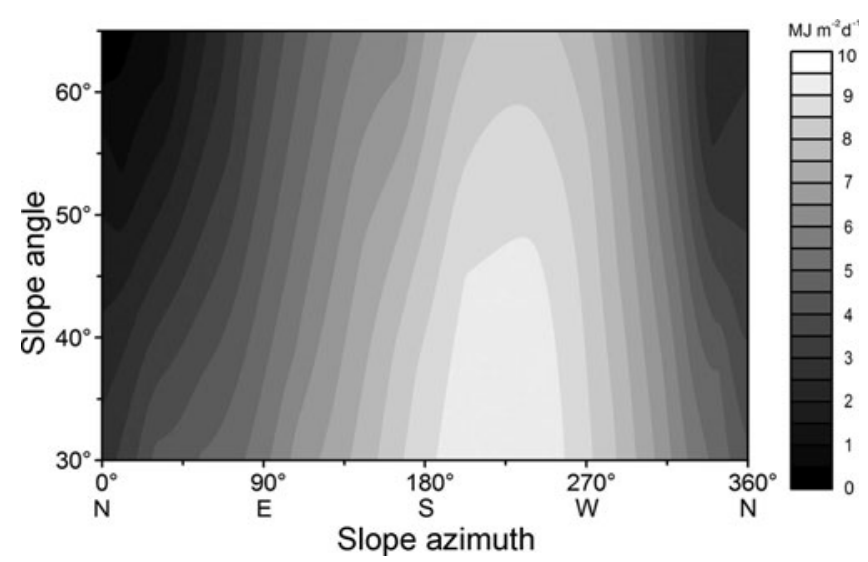

Fig. 6. Dependence of daily shortwave radiation for a unit sloped area on the slope orientation of ice cliffs, considering the effect of cloud and scatter in the atmosphere, mapped using calculated daily shortwave radiation for all 38 ice cliffs in the debris-covered area on Koxkar glacier from 5 August to 5 September 2008.

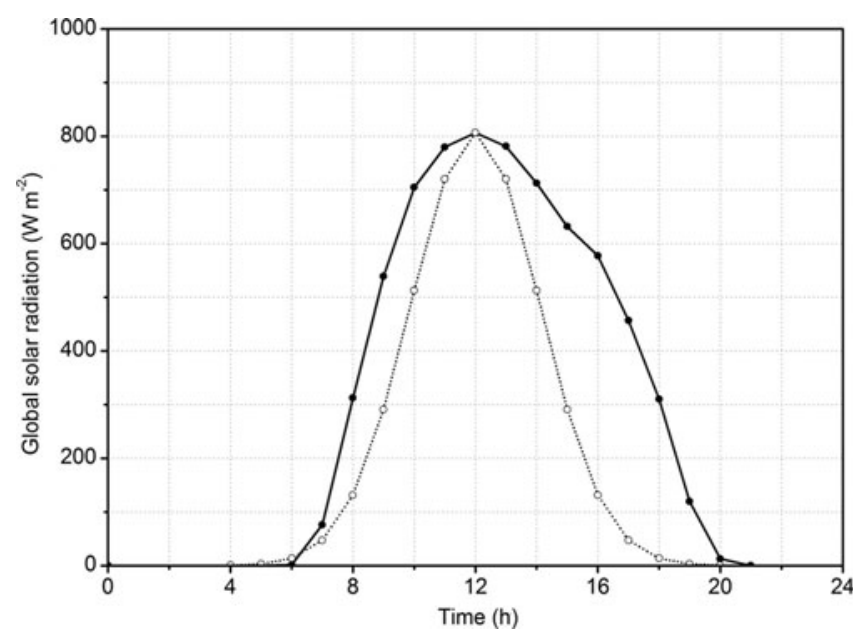

Fig. 7. Variations of mean global solar radiation (solid curve) during the study period compared with a normal distribution curve (dotted curve, $\sigma=2.1$ ), showing the asymmetry of global solar radiation with time.

incidence is acute. In the light of the model performance, however, this overestimation is acceptable.

Turbulent fluxes are also important components in the energy-balance equation over the ice-cliff slope. By applying the standard procedure to estimate turbulent fluxes over complex terrain, the large uncertainty is the exchange coefficient which may change significantly with slope orientation. It was pointed out that when the wind is perpendicular to a smooth surface the exchange coefficient, or more exactly the drag coefficient, is one order greater than when it is parallel (e.g. Thom, 1975). In our model the effect of exchange coefficient with slope orientation was handled by introducing a topographic-dependent roughness length which varies with wind direction and slope angle. Even though Lettau's (1969) model cannot reproduce the effect of mutual sheltering for higher topography (Bottema, 1996), it is very simple and the relevant variables can be readily measured in the field or from satellite images, which may be important when applying the model in an area with limited data availability. The wind-tunnel experiments and practical trials showed that Lettau's (1969) model performs well (Petersen, 1997; Duijm, 1999), and it also runs reasonably in the proposed model according to our calculation.

\section{Solar radiation and energy balance}

On the basis of the model calculation for all 38 ice cliffs during the observation period, Figure 6 shows the dependence of daily direct shortwave irradiance for a unit sloped area on the slope orientation of the ice cliff, considering the effect of cloud and scatter in the atmosphere. It shows that, for any given slope angle, the maximum direct solar radiation over the ice-cliff surface occurs at the southwest orientation. When the azimuth increases or decreases from this direction, the direct shortwave radiation decreases, reaching a minimum at around north as expected. Generally, the highest insolation on a clear day is found on the slope facing due south. The shift in orientation receiving the maximum insolation in the present case may be due to the asymmetric distribution of the hourly global solar radiation during the study period. As shown in Figure 7, the observed 


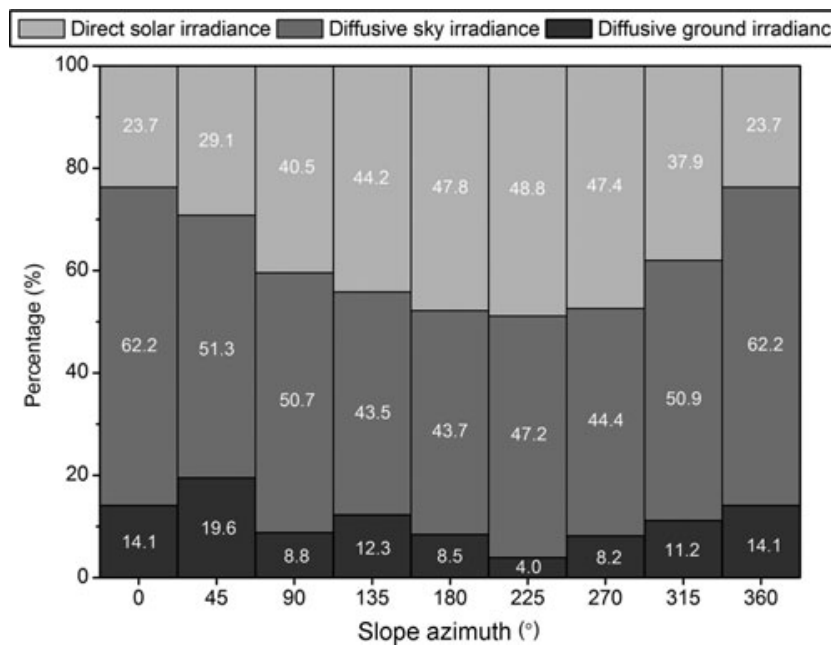

Fig. 8. Proportions of shortwave components reaching the ice-cliff slope for different azimuth slope angles, plotted based on calculation for all 38 ice cliffs from 5 August to 5 September 2008.

global solar radiation was significantly larger in the afternoon than at the corresponding times in the morning; this increases the accumulated shortwave radiation reaching a slope with a westerly azimuth compared with a slope facing east, so that the western shift in orientation receives the maximum insolation. The larger proportion of direct solar radiation found at ice cliffs facing west rather than east (Fig. 6) is similarly explained. The steep contours in Figure 6 indicate that, to some extent, the variation of shortwave radiation may be more sensitive to azimuth angle than to ice-cliff inclination angle, and this is more true for ice cliffs facing west than for those facing east.

As well as direct solar radiation, diffusive shortwave irradiance from the atmosphere and the surrounding topography contribute significantly to ice-cliff melt. As shown in Figure 8, the proportion of diffusive sky irradiance to total shortwave radiation over the ice-cliff surface ranged from $43.5 \%$ to $62.2 \%$, and diffusive ground irradiance from $4.0 \%$ to $19.6 \%$. Due to the high frequency of cloudy hours in the debris-covered area, the quantity of direct solar beam arriving at the ice-cliff slopes varied significantly with coefficient of variation, $C_{\mathrm{v}}=0.73$. In comparison, diffusive shortwave irradiance shows less variation, with averages of 7.1 and $1.5 \mathrm{MJ} \mathrm{m}^{-2} \mathrm{~d}^{-1}$ for diffusive sky irradiance $\left(C_{\mathrm{v}}=0.25\right)$ and diffusive irradiance from surrounding terrain $\left(C_{\mathrm{v}}=0.49\right)$.

For clarification, the daily averaged heat-balance elements for ice cliff F5 (Fig. 1; elevation 3191 m, slope angle $55^{\circ}$, azimuth angle $292^{\circ}$ ) from 5 August to 5 September are shown in Figure 9, as an example of the proportion and variation of heat components for an ice slope. It is seen that the net shortwave radiation is the most important heat source for ice-cliff ablation, contributing about $76 \%$ of the total heat available for ice melt. Due to the frequent influence of cloud, solar radiation varies significantly from 4.2 to $14.3 \mathrm{MJ} \mathrm{m}^{-2} \mathrm{~d}^{-1}$ in the case of $\mathrm{F} 5$, and for all the studied ice cliffs it varies in the range $2.0-15.5 \mathrm{MJ} \mathrm{m}^{-2} \mathrm{~d}^{-1}$ in our calculation. Owing to the large differences between air temperature and ice-cliff surface temperature during the melt season, the sensible heat flux is the secondary contributor to ice-cliff ablation, being responsible for nearly $24 \%$ of total heat for ice-cliff wastage. The latent heat flux

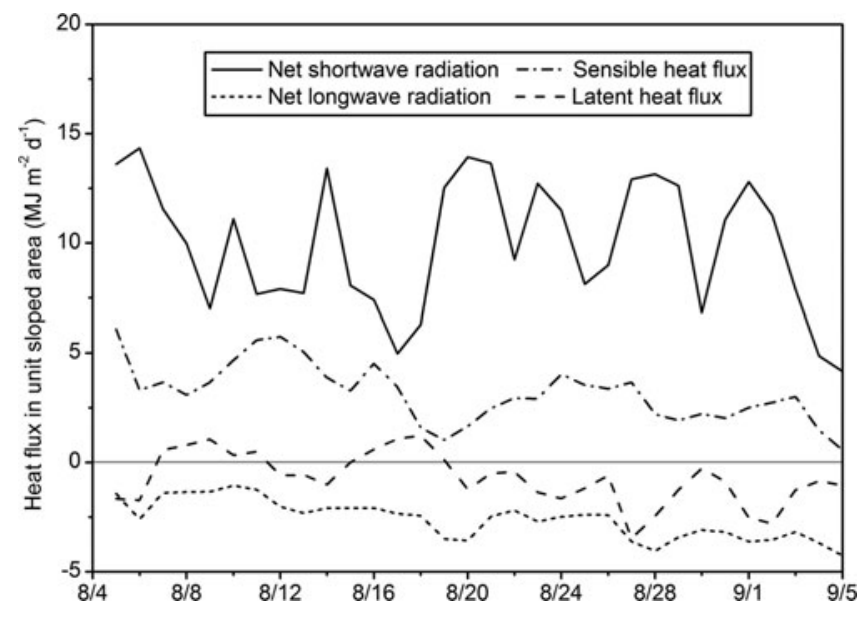

Fig. 9. Heat-balance elements at ice cliff F5 from 5 August to 5 September 2008. Dates are month/day.

was, however, small during the study period, compared to the sensible heat flux. Likewise, net longwave radiation is not significant for ice-cliff melting. Daily mean net longwave radiation is found to be $-2.6 \mathrm{MJ} \mathrm{m}^{-2} \mathrm{~d}^{-1}$ for ice cliff F5. Note that when air temperatures are low, as observed from 28 August to 5 September, heat loss due to net longwave radiation may be considerable. This was attributed to the significant drops both in diffusive sky and in diffusive ground irradiances reaching the ice-cliff surface.

\section{Backwasting rate for the melt season}

On the basis of the above proposed energy-balance model, backwasting rates for all 38 ice cliffs during the 2008 melt season, i.e. 1 May-31 October, were estimated using observed meteorological records at the three AWSs. The procedures for model data preparation for the ablation period duplicated those for the experimental period $5 \mathrm{Au}$ gust-5 September. The assumption of a consistent $0^{\circ} \mathrm{C}$ temperature at the ice-cliff face was maintained to facilitate the calculation, though the surface temperature of the ice cliff may be lower than $0^{\circ} \mathrm{C}$ in early May and late October.

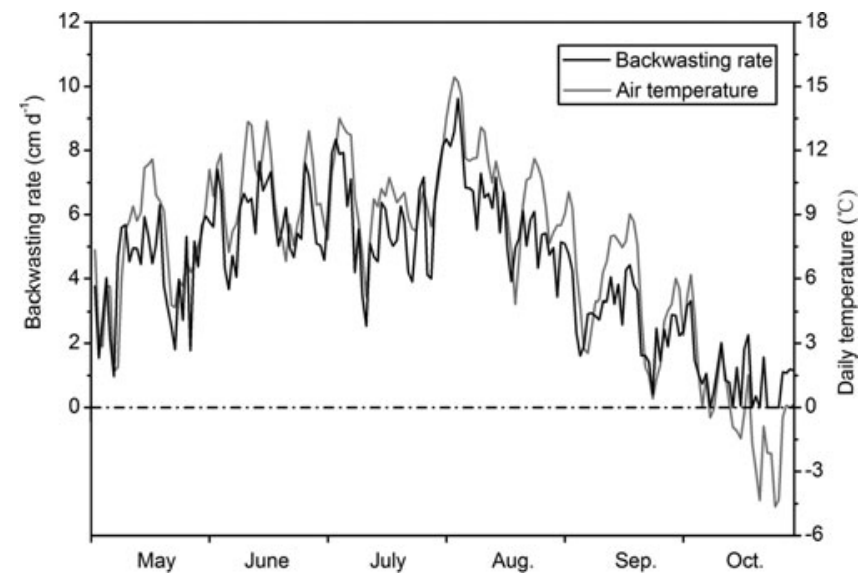

Fig. 10. Variations of estimated backwasting rate and daily mean air temperature at ice cliff F5 during the 2008 melt season. The black curve shows the variations in backwasting rate. The grey curve is the corresponding daily mean temperature at the site. 


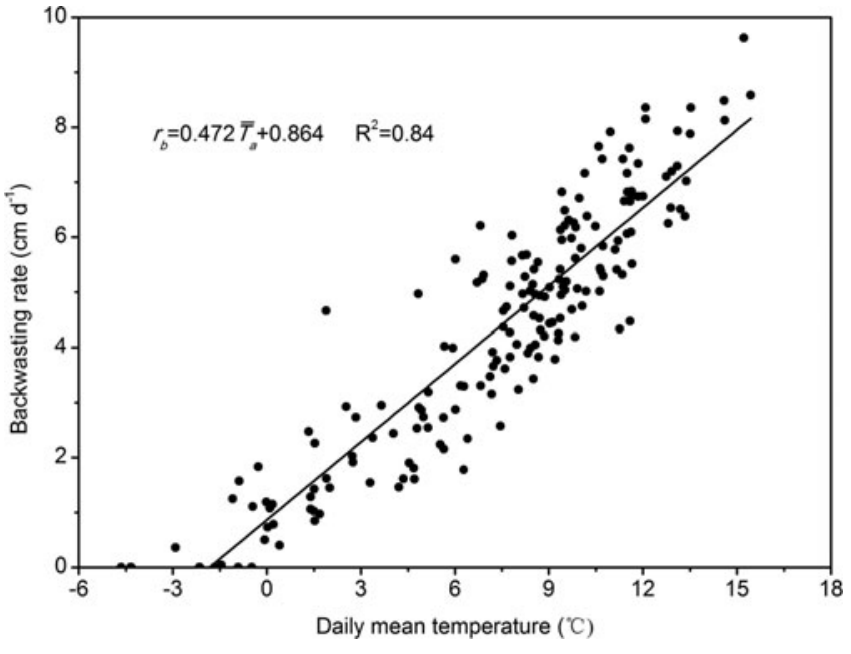

Fig. 11. Estimated backwasting rate, $r_{\mathrm{b}}$, versus daily mean air temperature, $\bar{\tau}_{\mathrm{a}}$, at ice cliff F5 during the 2008 melt season.

As an example, the daily variation of backwasting rates for ice cliff $\mathrm{F} 5$ is shown in Figure 10, together with interpolated daily mean air temperature at F5. It is observed that the fastest backwasting of F5 during the 2008 melt season occurs in early August, with a maximum rate of $9.6 \mathrm{~cm} \mathrm{~d}^{-1}$. The backwasting is also retarded significantly in October due to a rapid drop in temperature. The relationship between backwasting rates and daily mean temperatures (Figs 10 and 11) suggests there is a fairly strong correlation between backwasting rate and temperature. This may allow backwasting rate to be estimated using statistical backwasting-temperature models (e.g. a positive degreeday model) for areas where meteorological observations are limited.

Overall, the backwasting of all 38 ice cliffs ranges from 4.43 to $11.42 \mathrm{~m}$ during the 2008 melt season, and gives a mean value of $7.64 \mathrm{~m}$, or, alternatively, $7.64 \mathrm{~m} \mathrm{a}^{-1}$ given that winter ablation is neglected. The annual backwasting rate of ice cliffs is comparable with that on Kötlujökull, Iceland (7.1 $\mathrm{m} \mathrm{a}^{-1}$ (Krüger and Kjær, 2000)), and Larsbreen, Svalbard $\left(7 \mathrm{~m} \mathrm{a}^{-1}\right.$ (Lukas and others, 2005)), but is lower than that on glaciers in the Himalaya $\left(\sim 15 \mathrm{~m} \mathrm{a}^{-1}\right.$ (Sakai and others, 1998, 2002; Benn and others, 2001)) where meteorological conditions are comparable but the melt season lasts much longer than in the study area.

Based on the snapshot of ice-cliff distribution in 2006 (Fig. 2) and given a fixed inclination angle of $46.4^{\circ}$, the mean backwasting over all ice cliffs in the debris-covered area on Koxkar glacier will produce about $1.60 \times 10^{6} \mathrm{~m}^{3}$ of meltwater. According to mass-balance measurements, the total meltwater from the debris-covered area is of order $22 \times 10^{6} \mathrm{~m}^{3}$. Therefore, ice-cliff backwasting accounts for about $7.3 \%$ of the total from the debris-covered area. This is a much lower ratio than for Lirung glacier, Himalaya $(69 \%$ (Sakai and others, 1998)), due to more intense melting of the buried ice on Koxkar glacier ( $\sim 0.88 \mathrm{~cm} \mathrm{~d}^{-1}$ on average) than on Lirung glacier $\left(0.19 \mathrm{~cm} \mathrm{~d}^{-1}\right.$ (Rana and others, 1997)). The large discrepancy in daily melt rate between the two glaciers may be attributed to the differences in average debris thickness $(0.53 \mathrm{~m}$ for Koxkar glacier and 0.5-1.0 $\mathrm{m}$ for Lirung glacier (Rana and others, 1996)), and in altitude of the ablation area (3060-4250 m a.s.I. for Koxkar glacier and 4000-4400 ma.s.I. for Lirung glacier (Gades and others,
2000)) which denotes the different air temperatures between two alpine environments.

\section{SUMMARY}

Revision of the Chinese Glacier Inventory is in progress, the main goal being to improve knowledge of the current status of glaciers in China and assess recent glacier changes. One of the challenges in this work is to assess ongoing changes in debris-covered glaciers in areas such as the Tuomuer mountain district, the Pamir plateau and the Himalaya where glaciers with extensive supraglacial debris are widespread. Thus, there is a need to improve the current understanding of the meltout of debris-covered glaciers through long-term field observations as well as quantitative assessments.

We have described a physically based energy-balance model to estimate the backwasting rate of ice cliffs in a debris-cover area with improved parameterization of solar radiation for a sloped ice surface. The model was tested against observations carried out on 38 ice cliffs within the debris-covered area on Koxkar glacier from 5 August to 5 September 2008.

In general, the energy-balance model gives a good estimate of the backwasting rates, with errors in the range $\pm 1.96 \mathrm{~cm} \mathrm{~d}^{-1}$ and RMSEs of $0.99 \mathrm{~cm} \mathrm{~d}^{-1}$. Errors arising from using fixed surface albedo and turbulent flux parameterization were limited. We calculated that the maximum incoming shortwave radiation to the ice-cliff surface occurs from the southwest, and as the azimuth increases or decreases from this direction, the incoming shortwave radiation decreases, reaching a minimum at around north. The incoming shortwave radiation decreases with increased slope angle at any given azimuth angle, and, to some extent, the variation of shortwave radiation over a sloped ice surface may be more sensitive to azimuth angle than to ice-cliff inclination angle.

Shortwave radiation is the most important heat source for ice-cliff ablation, contributing about $76 \%$ of the total energy available for ice melt, while the sensible heat flux supplies nearly $24 \%$ of total energy for ice-cliff wastage. According to the model calculation, latent heat flux and net longwave radiation are comparatively small.

The mean backwasting rate of ice cliffs within the debris cover on Koxkar glacier is estimated to be $7.64 \mathrm{~m} \mathrm{a}^{-1}$ in 2008 when winter ablation is neglected. With this annual backwasting rate and given a mean slope angle of $46.4^{\circ}$, the backwasting of ice cliffs will produce about $1.60 \times 10^{6} \mathrm{~m}^{3}$ of meltwater in 2006, and accounts for about $7.3 \%$ of total melt runoff from the debris-covered area.

The results are based on short-term field observations and are thus preliminary. The errors in the model calculation suggest that there is still much scope for model improvement. However, this model can provide detailed information on how energy is distributed on an inclined ice cliff and how ice melt is influenced by meteorological variables and glacier topography, which is very helpful for improving our understanding of the physical processes of ice-cliff backwasting. Though a physically based model may not always yield better results than a statistical model (e.g. degree-day model), the latter is usually based on the statistical relationship between ice melt and meteorological forces and thus is ambiguous in explaining how melt is affected. 
Continued long-term monitoring of ice-cliff backwasting is in progress in order to further validate the modeling results and improve the model for running on remotely sensed datasets. In the future, increased focus will be needed on improving the parameterization of turbulent heat fluxes, which may require observations of wind and temperature profiles perpendicular to the ice cliff, and comparison with horizontal measurements.

\section{ACKNOWLEDGEMENTS}

This work was supported by the Nation Basic Research Program of China (973 Program) under grant No. 2007CB411501, China International Science and Technology Cooperation Program under grant No. 2008DFA20400, National Basic S\&T Project of the Ministry of Science and Technology of the People's Republic of China under grant No. 2006FY110200, and National Nature Science Foundation of China (NSFC) program under grant No. 40601020. We thank Wang Shunde, Xu Jindong and Jiang Li for support in the field investigations and data collection. The manuscript was greatly improved by the invaluable comments and suggestions of J. Hulth, L. Nicholson, R. Braithwaite and B. Kulessa.

\section{REFERENCES}

Ambach, W. 1986. Nomographs for the determination of meltwater from snow- and ice surfaces. Ber. Naturwiss. Med. Vereins Innsbruck, 73, 7-15.

Andreas, E.L. 1987. A theory for the scalar roughness and the scalar transfer coefficients over snow and sea ice. Bound.-Layer Meteorol., 38(1-2), 159-184.

Benn, D.I. and D.J.A. Evans. 1998. Glaciers and glaciation. London, Arnold.

Benn, D.I., S. Wiseman and K.A. Hands. 2001. Growth and drainage of supraglacial lakes on the debris-mantled Ngozumpa Glacier, Khumbu Himal, Nepal. J. Glaciol., 47(159), 626-638.

Bottema, M. 1996. Roughness parameters over regular rough surfaces: experimental requirements and model validation. J. Wind Eng. Ind. Aerodyn., 64(2-3), 249-265.

Chou, M.-D. and M.J. Suarez. 1999. A solar radiation parameterization (CLIRAD-SW) for atmospheric studies. NASA Tech. Mem. 1999-104606.

Cole, R.J. 1979. The longwave radiation incident upon inclined surfaces. Sol. Energy, 22(5), 459-462.

Dozier, J. and J. Frew. 1990. Rapid calculation of terrain parameters for radiation modeling from digital elevation data. IEEE Trans. Geosci. Remote Sens., 28(5), 963-969.

Duijm, N.J. 1999. Estimates of roughness parameters for arrays of obstacles. Bound.-Layer Meteorol., 91(1), 1-22.

Fujii, Y. 1977. Field experiment on glacier ablation under a layer of debris cover. Seppyo, J. Jpn. Soc. Snow Ice, 39, Special Issue, 20-21.

Gades, A., H. Conway, N. Nereson, N. Naito and T. Kadota. 2000. Radio echo-sounding through supraglacial debris on Lirung and Khumbu Glaciers, Nepal Himalayas. IAHS Publ. 264 (Symposium at Seattle 2000 - Debris-Covered Glaciers), 13-22.

Garnier, B. and A. Ohmura. 1968. A method of calculating the direct shortwave radiation income on slopes. J. Appl. Meteorol., 7(5), 796-800.

Han, H. 2007. Modeling the ice ablation under a supraglacial debris layer: a case study of Koxkar Glacier, west Tianshan, China. (PhD thesis, Cold and Arid Regions Environmental and Engineering Research Institute, Chinese Academy of Sciences.)

Han, H., Y. Ding and S. Liu. 2005. Estimation and analysis of the heat balance parameters in summer season of the debris- covered Kerqikaer Glacier. J. Glaciol. Geocryol., 27(1), 88-94. [In Chinese with English summary.]

Han, H., Y. Ding and S. Liu. 2006. A simple model to estimate ice ablation under a thick debris layer. J. Glaciol., 52(179), 528-536.

Han, H. and 13 others. 2008. Near-surface meteorological characteristics on the Koxkar Baxi Glacier, Tianshan. J. Glaciol. Geocryol., 30(6), 967-975.

Han, H., S. Liu, J. Wang, Q. Wang and C. Xie. In press. Glacial runoff characteristics of the Koxkar Glacier, Tuomuer-Khan Tengri Mountain Ranges, China. Environ. Earth Sci. (10.1007/ s12665-009-0378-9.)

Iqbal, M. 1983. An introduction to solar radiation. New York, Academic Press.

Johnson, P.G. 1992. Stagnant glacier ice, St. Elias Mountains, Yukon. Geogr. Ann., 74A(1), 13-19.

Krüger, J. 1994. Glacial processes, sediments, landforms, and stratigraphy in the terminus region of Mýrdalsjökull, Iceland. Two interdisciplinary case studies. Folia Geogr. Dan., 21, 1-233.

Krüger, J. and K.H. Kjær. 2000. De-icing progression of ice-cored moraines in a humid, subpolar climate, Kötlujökull, Iceland. Holocene, 10(6), 737-747.

Lettau, H. 1969. Note on aerodynamic roughness-parameter estimation on the basis of roughness element description. J. Appl. Meteorol., 8(5), 828-832.

Loomis, S.R. 1970. Morphology and ablation processes on glacier ice. Assoc. Am. Geogr. Proc., 2, 88-92.

Lukas, S., L.I. Nicholson, F.H. Ross and O. Humlum. 2005. Formation, meltout processes and landscape alteration of highArctic ice-cored moraines: examples from Nordenskild Land, Central Spitsbergen. Polar Geogr., 29(3), 157-187.

Mattson, L.E., J.S. Gardner and G.J. Young. 1993. Ablation on debris covered glaciers: an example from the Rakhiot Glacier, Punjab, Himalaya. IAHS Publ. 218 (Symposium at Kathmandu 1992 - Snow and Glacier Hydrology), 289-296.

Østrem, G. 1959. Ice melting under a thin layer of moraine, and the existence of ice cores in moraine ridges. Geogr. Ann., 41(4), 228-230.

Petersen, R.L. 1997. A wind tunnel evaluation of methods for estimating surface roughness length at industrial facilities. Atmos. Environ., 31(1), 45-57.

Pickard, J. 1984. Retreat of ice scarps on an ice-cored moraine, Vestfold Hills, Antarctica. Z. Geomorphol., 28, 443-453.

Purdie, J. and B. Fitzharris. 1999. Processes and rates of ice loss at the terminus of Tasman Glacier, New Zealand. Global Planet. Change, 22(1-4), 79-91.

Rana, B., Y. Fukushima, Y. Ageta and M. Nakawo. 1996. Runoff modeling of a river basin with a debris-covered glacier in Langtang Valley, Nepal Himalaya. Bull. Glacier Res., 14, 1-6.

Rana, B., M. Nakawo, Y. Fukushima and Y. Ageta. 1997. Application of a conceptual precipitation-runoff model (HYCYMODEL) in a debris-covered glacierized basin in the Langtang Valley, Nepal Himalaya. Ann. Glaciol., 25, 226-231.

Reindl, D.T., W.A. Beckman and J.A. Duffie. 1990. Diffuse fraction correlations. Sol. Energy, 45(1), 1-7.

Sakai, A., M. Nakawo and K. Fujita. 1998. Melt rate of ice cliffs on the Lirung Glacier, Nepal Himalayas, 1996. Bull. Glacier Res., 16, 57-66.

Sakai, A., M. Nakawo and K. Fujita. 2002. Distribution characteristics and energy balance of ice cliffs on debris-covered glaciers, Nepal Himalaya. Arct. Antarct. Alp. Res., 34(1), 12-19.

Schomacker, A. and K.H. Kjær. 2008. Quantification of dead-ice melting in ice-cored moraines at the high-Arctic glacier Holmströmbreen, Svalbard. Boreas, 37(2), 211-225.

Sridhar, V. and R.L. Elliott. 2002. On the development of a simple downwelling longwave radiation scheme. Agric. Forest Meteorol., 112(3-4), 237-243.

Su, Z. and D. Gao, eds. 1985. Glaciology and meteorology in Mount Tuomuer region, Tien Shan. Ürümqi, Xijiang People's Press. [In Chinese with English summary.] 
Thom, A.S. 1975. Momentum, mass and heat exchange of plant communities. In Monteith, J.L., ed. Vegetation and the atmosphere. Vol. 1. Principles. San Diego, CA, Academic Press, 57-109.

Wang, Z., C. Liu and L. Ding. 1987. Development conditions and distribution features of the glaciers in the interior drainage area of Tarim Basin in southwest Tien Shan. In Xie, W., L. Ding, C. Liu, K. Jiao, C. Wang and Z. Wang, eds. Glacier inventory of China III.
Tien Shan. Beijing, Science Press. Academia Sinica, Lanzhou Institute of Glaciology and Geocryology, 7-69. [In Chinese.]

Wong, L.T. and W.K. Chow. 2001. Solar radiation model. Appl. Energy, 69(3), 191-224.

Xie, W., L. Ding, C. Liu, K. Jiao, C. Wang and Z. Wang, eds. 1987. Glacier inventory of China III. Tien Shan. Beijing, Science Press. Academia Sinica, Lanzhou Institute of Glaciology and Geocryology. [In Chinese.]

MS received 21 May 2009 and accepted in revised form 19 March 2010 